\title{
GAME MEAT MANAGEMENT IN SELECTED AREAS OF THE SIEDLCE HUNTING DISTRICT
}

\section{GOSPODARKA TUSZAMI ZWIERZAT ŁOWNYCH Z WYBRANYCH OBWODÓW SIEDLECKIEGO OKRĘGU ŁOWIECKIEGO}

\author{
Department of Reproduction and Animal Hygiene, Siedlce University of Natural Sciences \\ and Humanities, Poland \\ ${ }^{1}$ Department of Agronomy, Siedlce University of Natural Sciences and Humanities, Poland
}

\begin{abstract}
Streszczenie. Z pozyskanych tusz zwierząt łownych około $25 \%$ udostępnianych jest myśliwym na ich własny użytek, pozostałe przekazywane są do punktów skupu dziczyzny. Celem niniejszej pracy jest charakterystyka skupowanej dziczyzny (tj. gatunków zwierząt łownych, ilości i masy skupowanych tusz, klasy tuszy) z wybranych obwodów siedleckiego okręgu łowieckiego, z uwzględnieniem sezonu łowieckiego i pory roku. W badanych sezonach łowieckich w Punkcie Skupu Dziczyzny w Siedlcach (PSD) z analizowanych obwodów łowieckich skupiono 230 tusz dzika, co stanowiło $13438 \mathrm{~kg}$ łącznej masy tuszy. W sezonie łowieckim 2015/2016 była to wartość ponad 2,5-krotnie większa niż w sezonie 2014/2015, co mogło być związane ze zwiększeniem planowanego odstrzału tego gatunku z powodu szkód łowieckich i zagrożenia ASF. Średnia masa skupionych tusz dzika z badanych obwodów wynosiła 28-123 kg. Wykazano istotny wpływ sezonu łowieckiego i pory roku na średnią masę tuszy dzika. $Z$ terenu analizowanych obwodów skupiono w badanym okresie 149 tusz rogacza o łącznej masie $2795 \mathrm{~kg}$. Średnia masa tuszy sarny rogacza $z$ badanych obwodów wahała się w granicach $16-21 \mathrm{~kg}$. W badanych sezonach łowieckich, w okresie jesieni i zimy, przyjęto do skupu łącznie 138 tusz sarny kozy, co stanowiło masę $2454 \mathrm{~kg}$, przy czym średnia masa tuszy z badanych obwodów wynosiła $14-20 \mathrm{~kg}$. W obu sezonach łowieckich dostarczono również 27 tusz sarny koźlęcia o łącznej masie wynoszącej $360 \mathrm{~kg}$. Średnia masa tusz koźląt, dostarczonych do PSD z badanych obwodów, oscylowała w granicach $11-17 \mathrm{~kg}$. W przypadku tego gatunku nie wykazano statystycznie istotnych różnic średniej masy tuszy między badanymi sezonami łowieckimi i porami roku. Tusze badanych gatunków zwierząt były w większości tuszami I klasy.
\end{abstract}

Key words: game meat, game meat depots, boar, deer, hunting period, season.

Słowa kluczowe: dziczyzna, punkt skupu dziczyzny, dzik, sarna, sezon łowiecki, pora roku.

\section{INTRODUCTION}

The meat of animals living in the wild is a perfect alternative to that of slaughtered animals bred in intensive or semi-intensive conditions. Since such animals live in their natural habitat and actively search and consume food of their own choice throughout their life, their meat has a good structure, a specific taste and aroma, as well as outstanding dietary value (Ziembińska and Krasnowska 2007). Game does not contain feed hormones or antibiotics.

Corresponding author - Adres do korespondencji: Elżbieta Bombik, Department of Reproduction and Animal Hygiene, Siedlce University of Natural Sciences and Humanities, Bolesława Prusa 14, 08-110 Siedlce, Poland, e-mail: elzbieta.bombik@uph.edu.pl 
Moreover, the meat of properly hunted animals contains only an insignificant amount of stress hormones (Skorupski and Wierzbicka 2014). In comparison with the meat of farm animals, game contains less fat and more protein, while having a better fatty acid profile. Moreover, owing to its advantageous chemical composition, game is highly suitable for food processing (Werpachowski and Zalewski 2012). Modern game consumers prefer fresh and lean meat with a specific taste and aroma (Hoffman and Wiklund 2006; Ngapo and Dransfield 2006). Yet another significant aspect is the fact that a modern consumer looks for alternatives to the meat of farmed animals for ethical reasons as well as out of care about the impact of the product on the environment (Santos and Booth 1996; Steenkamp 1997; Bernués et al. 2003; Dransfield 2003). Some carcass parts obtained from wild animals are available for hunters for their own usage. However, hunting associations set aside about $75 \%$ of carcasses for companies dealing in game, the co-called game meat depots (Popczyk 2012). Such companies chiefly purchase carcasses of fallow deer, wild boars, deer and roe deer. According to the data from the General Veterinary Inspectorate (2016) in 2016 there were 1447 game depots registered in Poland.

This article was aimed at characterizing the traded game, i.e. defining the species of game animals, the numbers and weights of purchased carcasses and the quality of carcasses stocked at the Siedlce game depot. The research concerned selected areas in the Siedlce hunting district, with account taken of the hunting period and the season of the year.

\section{MATERIAL AND METHODS}

The data on the carcasses of wild animals were obtained from the PSD (Punkt Skupu Dziczyzny, game depot) located in the Siedlce hunting district. The data included information from 11 hunting areas in 2 hunting periods: 2014/2015 and 2015/2016 (Fig. 1).

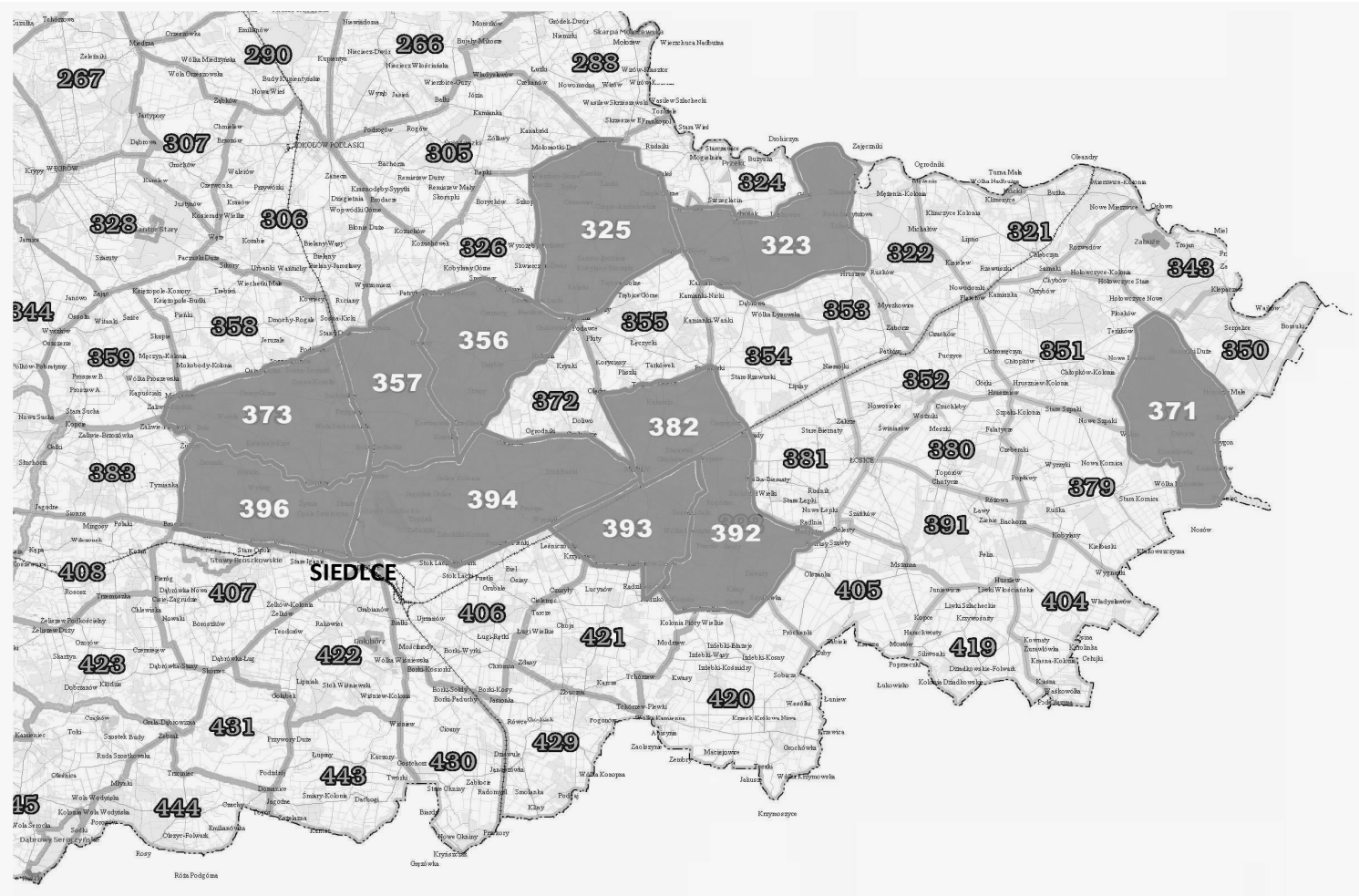

Fig. 1. Location of studied areas of Siedlce hunting district

Ryc. 1. Lokalizacja badanych obwodów siedleckiego okręgu łowieckiego 
The procedure of obtaining the carcasses of roe deer and wild boars is presented in particular seasons of the year: spring, summer, autumn and winter. The spring months include: April, May and June; summer: July, August and September; autumn: October, November and December; and winter: January, February and March. The purchased game was analyzed in respect of the animal species, the numbers and weights of the carcasses and the quality of the carcasses delivered to the PSD from the selected zones in the Siedlce hunting district, allowing for the hunting period and seasons of the year. The game was purchased according to the game animal classification of Weles Sp. z o.o. (Klasyfikacja dziczyzny, http://www.weles.pl/informacje). The study results were statistically processed in a bidirectional non-orthogonal analysis of variation. The means were compared using Tukey's range test $(P \leq 0.05)$.

\section{RESULTS AND DISCUSSION}

The game meat depot in Siedlce (PSD) received carcasses of deer, wild boars and roe deer from the examined hunting zones. Most of the analysed carcasses were purchased by the Siedlce PSD as first quality game meat. Due to a small number of deer carcasses (5) delivered to the PSD, an analysis of this species was not possible for one of the hunting districts.

230 carcasses of wild boars were purchased in the examined period (Table 1). 166 carcasses of wild boars were purchased in the hunting period of 2015/2016, i.e. a hundred more than during the hunting period of 2014/2015. This proved to be a statistically significant difference $(P \leq 0.05)$. According to the Regulation of the Minister of Agriculture and Rural Development, dated 19th February 2016, on wild boar sanitary shooting (Rozporządzenie Ministra Rolnictwa i Rozwoju Wsi z 19 lutego 2016 r.), a higher number of wild boar shootings were carried out by hunting associations in 2015/2016 in connection with cases of African Swine Fever (ASF) in Poland. An analysis of season influence on the numbers of wild boar carcasses stocked in the PSD revealed that statistically significantly more carcasses were purchased in the spring of the 2015/2016 hunting period in comparison with the same time of the previous period. The highest number of wild boar carcasses were purchased in the autumn both in the 2014/2015 and 2015/2016 hunting periods. The 394th hunting zone provided the most carcasses of this species for the depot. The share of wild boar carcasses in the meat purchased as first quality game in the examined seasons was $73 \%$. The total weight of purchased wild boar carcasses amounted to $13438 \mathrm{~kg}$ in the period under analysis (Table 2). The respective total weight in the hunting period of 2015/2016 was $8932 \mathrm{~kg}$, i.e. twice the amount of the previous period. The highest total weight of carcasses purchased by the depot in the analysed hunting periods was provided by the 394th zone. The highest total weight of wild boar carcasses was bought in the autumn in both hunting periods, 2014/2015 and 2015/2016. The mean weight of the wild boar carcasses purchased from the studied zones ranged from $28 \mathrm{~kg}$ to $123 \mathrm{~kg}$ (Table 3). The analysis of the wild boar carcass weight means revealed significant differences $(P \leq 0.05)$ between the examined hunting periods and seasons of the year. In the hunting period of 2015/2016 the mean weight of the purchased wild boar carcasses was significantly lower (by $16.6 \mathrm{~kg}$ ) than in the previous period. In the summer of the hunting period 2014/2015 a statistically significantly 
higher mean weight of wild boar carcasses was delivered to the PSD $(74.5 \mathrm{~kg})$ in comparison with the same season in the period of 2015/2016 $(57.5 \mathrm{~kg})$. We also found the mean weight of the wild boar carcasses was lower in the spring than in the other seasons $(P \leq 0.05)$.

Table 1. The numbers (pieces) and quality (percentage of class I carcasses) of the purchased boar carcasses (Sus scrofa L.) from the selected hunting zones (numbers given in brackets) of the Siedlce district and their extreme values in relation to the hunting period and the season of the year

Tabela 1. Liczba oraz jakość (procentowy udział tusz I klasy) tusz dzika (Sus scrofa L.) skupionych z wybranych obwodów siedleckiego okręgu łowieckiego (podanych w nawiasach) oraz ich wartości ekstremalne, w zależności od sezonu łowieckiego i pory roku

\begin{tabular}{|c|c|c|c|c|}
\hline $\begin{array}{l}\text { Hunting } \\
\text { period } \\
\text { Sezon } \\
\text { łowiecki }\end{array}$ & $\begin{array}{l}\text { Season } \\
\text { Pora roku }\end{array}$ & $\begin{array}{c}\text { Extreme values } \\
\text { Wartości ekstremalne }\end{array}$ & $\begin{array}{c}\text { Total } \\
\text { Razem }\end{array}$ & $\begin{array}{c}\text { Percentage } \\
\text { of class I } \\
\text { carcasses } \\
\text { Procentowy } \\
\text { udział tusz } \\
\text { I klasy }\end{array}$ \\
\hline \multirow{4}{*}{$2014 / 2015$} & spring - wiosna & $0(325,323,356,357,371,373,382,392)-3(394)$ & $6^{* *}$ & 83.3 \\
\hline & summer - lato & $0(325,357,356,373,382,396)-6(394)$ & 10 & 70.0 \\
\hline & autumn - jesień & $0(373,396)-10(394)$ & 35 & 81.2 \\
\hline & winter - zima & $0(325,392,396)-3(394)$ & 13 & 92.3 \\
\hline \multicolumn{3}{|c|}{ Period total - Razem w sezonie } & $64^{*}$ & 78.1 \\
\hline \multirow{4}{*}{$2015 / 2016$} & spring - wiosna & $0(373,396)-18(394)$ & $44^{* *}$ & 68.2 \\
\hline & summer - lato & $0(325,356,373,396)-20(394)$ & 43 & 86.0 \\
\hline & autumn - jesień & $0(396)-12(394)$ & 49 & 69.4 \\
\hline & winter - zima & $0(325,356,382)-11(393)$ & 30 & 56.7 \\
\hline \multicolumn{3}{|c|}{ Period total - Razem w sezonie } & $166^{*}$ & 71.1 \\
\hline \multicolumn{3}{|c|}{ Entire time span total - Razem w sezonach } & 230 & 73.0 \\
\hline
\end{tabular}

*Significant period differences and ${ }^{* *}$ in the spring in the periods - ${ }^{*}$ Istotne różnice w sezonach oraz ${ }^{* *}$ wiosną w sezonach.

Table 2. Total carcass weights [kg] of the purchased boar carcasses (Sus scrofa L.) from the selected hunting zones (numbers given in brackets) of the Siedlce district and their extreme values in relation to hunting period and the season of the year

Tabela 2. Łączna masa [kg] tusz dzika (Sus scrofa L.) skupionych z wybranych obwodów siedleckiego okręgu łowieckiego (podanych w nawiasach) oraz ich wartości ekstremalne, w zależności od sezonu łowieckiego i pory roku

\begin{tabular}{|c|c|c|c|c|c|}
\hline \multirow{2}{*}{$\begin{array}{l}\text { Season } \\
\text { Pora roku }\end{array}$} & \multicolumn{2}{|c|}{$\begin{array}{l}\text { Period - Sezon } \\
2014 / 2015\end{array}$} & \multicolumn{2}{|l|}{$\begin{array}{c}\text { Period - Sezon } \\
2015 / 2016\end{array}$} & \multirow{2}{*}{$\begin{array}{l}\text { Total } \\
\text { Razem }\end{array}$} \\
\hline & $\begin{array}{c}\text { extreme values } \\
\text { wartości ekstremalne }\end{array}$ & $\begin{array}{l}\text { total } \\
\text { razem }\end{array}$ & $\begin{array}{c}\text { extreme values } \\
\text { wartości ekstremalne }\end{array}$ & $\begin{array}{l}\text { total } \\
\text { razem }\end{array}$ & \\
\hline Spring - Wiosna & $48(396)-181(394)$ & 297 & $28(357)-662(394)$ & 1810 & 2117 \\
\hline Summer - Lato & $60(393)-431(394)$ & 746 & $47(371)-1150(394)$ & 2472 & 3218 \\
\hline Autumn - Jesień & $75(325)-650(394)$ & 2583 & $48(373)-670(394)$ & 3050 & 5633 \\
\hline Winter - Zima & $35(357)-242(394)$ & 880 & $60(373,396)-536(393)$ & 1600 & 2481 \\
\hline \multicolumn{2}{|c|}{ Period total - Razem w sezonie } & 4506 & & 8932 & \\
\hline \multicolumn{3}{|c|}{ Entire time span total - Razem w sezonach } & & & 13438 \\
\hline
\end{tabular}


Table 3. Mean carcass weights $[\mathrm{kg}]$ of the purchased boar carcasses (Sus scrofa L.) and their extreme values in relation to the hunting period and the season of the year

Tabela 3. Średnia masa [kg] skupionych tusz dzika (Sus strofa L.) oraz ich wartości ekstremalne (podane w nawiasach) w analizowanych sezonach łowieckich i porach roku

\begin{tabular}{|c|c|c|c|c|c|}
\hline \multirow{2}{*}{$\begin{array}{l}\text { Hunting period } \\
\text { Sezon łowiecki }\end{array}$} & \multicolumn{4}{|c|}{ Season - Pora roku } & \multirow{2}{*}{$\begin{array}{l}\text { Hunting } \\
\text { period mean } \\
\text { Średnia } \\
\text { dla sezonu } \\
\text { łowieckiego }\end{array}$} \\
\hline & $\begin{array}{l}\text { spring } \\
\text { wiosna }\end{array}$ & $\begin{array}{l}\text { summer } \\
\text { lato }\end{array}$ & $\begin{array}{l}\text { autumn } \\
\text { jesień }\end{array}$ & $\begin{array}{l}\text { winter } \\
\text { zima }\end{array}$ & \\
\hline $2014 / 2015$ & $\begin{array}{c}49.5^{a} \\
(34.0-60.3)\end{array}$ & $\begin{array}{c}74.6^{\mathrm{b}} \\
(60.0-123.0)\end{array}$ & $\begin{array}{c}73.8^{\mathrm{a}} \\
(58.0-92.0)\end{array}$ & $\begin{array}{c}67.7^{a} \\
(35.0-80.7)\end{array}$ & $70.4^{b}$ \\
\hline $2015 / 2016$ & $\begin{array}{c}41.1^{\mathrm{a}} \\
(28.0-58.3)\end{array}$ & $\begin{array}{c}57.5^{\mathrm{a}} \\
(45.0-73.0)\end{array}$ & $\begin{array}{c}62.3^{a} \\
(41.8-81.0)\end{array}$ & $\begin{array}{c}53.4^{\mathrm{a}} \\
(48.7-69.0)\end{array}$ & $53.8^{\mathrm{a}}$ \\
\hline $\begin{array}{l}\text { Season mean } \\
\text { Średnia dla pory roku }\end{array}$ & $42.1^{\mathrm{a}}$ & $60.7^{b}$ & $67.1^{b}$ & $57.7^{\mathrm{b}}$ & \\
\hline
\end{tabular}

$a, b-$ mean values marked with these letters do not differ significantly $(P \leq 0.05)$ - średnie oznaczone tymi samymi literami nie różnią się istotnie $(P \leq 0,05)$.

Altogether 149 carcasses of roe bucks were delivered to the PSD in the examined time span, 71 in 2014/2015 and 78 in the following period (Table 4). Similar numbers of roe buck carcasses were delivered both in the spring and summer. Zone 394 was found to have provided the highest number of roe buck carcasses in both periods. The share of roe buck carcasses in the meat bought as first quality game in the studied periods was $82.2 \%$. $2795 \mathrm{~kg}$ of roe buck carcasses were bought during the time span under analysis (Table 5). $1458 \mathrm{~kg}$ of carcasses, i.e. $121 \mathrm{~kg}$ more than previously, were purchased in the hunting period of 2015/2016. The 394th hunting zone delivered the highest weight of carcasses to the PSD in both periods. The mean weight of roe buck carcasses stocked in the PSD in the hunting period of 2014/2015 from the areas under scrutiny oscillated between 15 and $21 \mathrm{~kg}$. In the following hunting period it ranged from 16 to $20 \mathrm{~kg}$ (Table 6). No statistically important differences were noticed between the roe buck carcass weight means in the examined periods and seasons.

Table 4. Numbers (pieces) and quality (\% of class I carcasses) of the purchased roebuck carcasses (Capreolus capreolus L.) from the selected hunting zones (numbers given in brackets) of the Siedlce district and their extreme values in relation to the hunting period and the season of the yearperiod Tabela 4. Liczba oraz jakość (udział tusz I klasy w \%) tusz sarny rogacza (Capreolus capreolus L.) skupionych z wybranych obwodów siedleckiego okręgu łowieckiego (podanych w nawiasach) oraz ich wartości ekstremalne, w zależności od sezonu łowieckiego i pory roku

\begin{tabular}{lcccc}
\hline $\begin{array}{c}\text { Hunting period } \\
\text { Sezon } \\
\text { łowiecki }\end{array}$ & $\begin{array}{c}\text { Season } \\
\text { Pora roku }\end{array}$ & $\begin{array}{c}\text { Extreme values } \\
\text { Wartości ekstremalne }\end{array}$ & $\begin{array}{c}\text { Total } \\
\text { Razem }\end{array}$ & $\begin{array}{c}\text { Percentage of class I } \\
\text { carcasses } \\
\text { Procentowy udział } \\
\text { tusz I klasy }\end{array}$ \\
\hline $2014 / 2015$ & spring - wiosna & $0(325,356)-7(373,394)$ & 32 & 84.4 \\
\hline summer - lato & $0(371,393)-12(394)$ & 39 & 84.6 \\
\hline $\begin{array}{l}\text { Period total } \\
\text { Razem w sezonie }\end{array}$ & spring - wiosna & $0(323,325,356,371)-15(394)$ & 39 & 84.5 \\
\hline $2015 / 2016$ & summer - lato & $0(357,373,393)-10(382)$ & 39 & 84.6 \\
\hline $\begin{array}{l}\text { Period total } \\
\text { Razem w sezonie }\end{array}$ & & 78 & 80.8 \\
\hline $\begin{array}{l}\text { Entire time span total } \\
\text { Razem w sezonach }\end{array}$ & & 149 & 82.6 \\
\hline
\end{tabular}


Table 5. Total carcass weights [kg] of the purchased roebuck carcasses (Capreolus capreolus L.) from the selected hunting zones (numbers given in brackets) of the Siedlce district and their extreme values in relation to the hunting period and the season of the year

Tabela 5. Łączna masa [kg] tusz sarny rogacza (Capreolus capreolus L.) skupionych z wybranych obwodów siedleckiego okręgu łowieckiego (podanych w nawiasach) oraz ich wartości ekstremalne, w zależności od sezonu łowieckiego i pory roku

\begin{tabular}{|c|c|c|c|c|c|}
\hline \multirow{2}{*}{$\begin{array}{l}\text { Season } \\
\text { Pora roku }\end{array}$} & \multicolumn{2}{|c|}{ Period - Sezon 2014/2015 } & \multicolumn{2}{|c|}{ Period - Sezon 2015/2016 } & \multirow{2}{*}{$\begin{array}{c}\text { Total } \\
\text { Razem }\end{array}$} \\
\hline & $\begin{array}{c}\text { extreme values } \\
\text { wartości ekstremalne }\end{array}$ & $\begin{array}{l}\text { total } \\
\text { razem }\end{array}$ & $\begin{array}{c}\text { extreme values } \\
\text { wartości ekstremalne }\end{array}$ & $\begin{array}{l}\text { total } \\
\text { razem }\end{array}$ & \\
\hline Spring - Wiosna & $18(357)-141(373)$ & 611 & $35(382)-298(394)$ & 755 & 1366 \\
\hline Summer - Lato & $17(392)-239(394)$ & 726 & $16(325)-178(382)$ & 703 & 1429 \\
\hline \multicolumn{2}{|c|}{ Period total - Razem w sezonie } & 1337 & & 1458 & \\
\hline \multicolumn{3}{|c|}{ Entire time span total - Razem w sezonach } & & & 2795 \\
\hline
\end{tabular}

Table 6. Mean carcass weights [kg] of the purchased roebuck carcasses (Capreolus capreolus L.) and their extreme values in relation to the hunting period and the season of the year

Tabela 6. Średnia masa [kg] skupionych tusz sarny rogacza (Capreolus capreolus L.) oraz ich wartości ekstremalne (podane w nawiasach) w analizowanych sezonach łowieckich i porach roku

\begin{tabular}{|c|c|c|c|}
\hline \multirow{2}{*}{$\begin{array}{l}\text { Hunting period } \\
\text { Sezon łowiecki }\end{array}$} & \multicolumn{2}{|c|}{ Season - Pora roku } & \multirow{2}{*}{$\begin{array}{c}\text { Hunting period mean } \\
\text { Średnia dla sezonu łowieckiego }\end{array}$} \\
\hline & spring - wiosna & summer - lato & \\
\hline $2014 / 2015$ & $\begin{array}{c}19.1 \\
(15.0-21.0) \\
\end{array}$ & $\begin{array}{c}18.6 \\
(17.0-20.3) \\
\end{array}$ & 18.8 \\
\hline $2015 / 2016$ & $\begin{array}{c}19.4 \\
(17.5-20.0)\end{array}$ & $\begin{array}{c}18.0 \\
(16.0-20.0)\end{array}$ & 18.7 \\
\hline $\begin{array}{l}\text { Season mean } \\
\text { Średnia dla pory roku }\end{array}$ & 19.2 & 18.3 & \\
\hline
\end{tabular}

Altogether 138 roe deer female carcasses were delivered to the PSD from the examined areas (Table 7).

Table 7. Numbers (pieces) and quality (\% of class I carcasses) of the purchased roe deer doe carcasses (Capreolus capreolus L.) from the selected hunting zones (numbers given in brackets) of the Siedlce district and their extreme values in relation to the hunting period and the season of the year Tabela 7. Liczba oraz jakość (udział tusz I klasy w \%) tusz sarny kozy (Capreolus capreolus L.) skupionych z wybranych obwodów siedleckiego okręgu łowieckiego (podanych w nawiasach) oraz ich wartości ekstremalne, w zależności od sezonu łowieckiego i pory roku

\begin{tabular}{lcccc}
\hline $\begin{array}{l}\text { Hunting period } \\
\text { Sezon łowiecki }\end{array}$ & $\begin{array}{c}\text { Season } \\
\text { Pora roku }\end{array}$ & $\begin{array}{c}\text { Extreme values } \\
\text { Wartości ekstremalne }\end{array}$ & $\begin{array}{c}\text { Total } \\
\text { Razem }\end{array}$ & $\begin{array}{c}\text { Percentage of class I } \\
\text { carcasses } \\
\text { Procentowy udział } \\
\text { tusz I klasy }\end{array}$ \\
\hline \multirow{2}{*}{$2014 / 2015$} & $\begin{array}{l}\text { autumn - jesień } \\
\text { winter - zima }\end{array}$ & $0(325,357,373)-14(394)$ & 33 & 93.9 \\
\hline Period total - Razem w sezonie & $0(371)-6(325,394)$ & 30 & 86.7 \\
\hline $2015 / 2016$ & autumn - jesień & $1(323,371)-10(396)$ & 63 & 90.5 \\
\hline Period total - Razem w sezonie & $0(325,356,371,373,393)-7(394)$ & 28 & 91.4 \\
\hline \multicolumn{2}{l}{ Entire time span total - Razem w sezonach } & 75 & 92.9 \\
\hline
\end{tabular}


75 carcasses were stocked in the 2015/2016 hunting period, i.e. 12 more in comparison with the previous one. The highest number of roe deer carcasses came from Zone 394. In both examined periods more pieces were delivered in the autumn than in the winter. The participation of roe deer female carcasses bought as first quality game was $91,3 \%$. The total weight of the purchased roe deer female carcasses in the examined period amounted to $2454 \mathrm{~kg}$ (Table 8). In the hunting period of 2015/2016 the PSD received $1338 \mathrm{~kg}$ of roe deer female carcasses, i.e. $222 \mathrm{~kg}$ more than in the previous period. Higher weight carcasses were bought in the autumn. The mean weight of a single purchased carcass in the examined zones was between 14 and $20 \mathrm{~kg}$ (Table 9). No statistically important differences were noticed between the roe deer carcasses mean weights in the examined periods and seasons.

Table 8. Total carcass weights [kg] of the purchased roe deer doe carcasses (Capreolus capreolus L.) from the selected hunting zones (numbers given in brackets) of the Siedlce district and their extreme values in relation to the hunting period and the season of the year

Tabela 8. Łączna masa tusz [kg] sarny kozy (Capreolus capreolus L.) skupionych z wybranych obwodów siedleckiego okręgu łowieckiego (podanych w nawiasach) oraz ich wartości ekstremalne, w zależności od sezonu łowieckiego i pory roku

\begin{tabular}{|c|c|c|c|c|c|}
\hline \multirow{2}{*}{$\begin{array}{l}\text { Season } \\
\text { Pora roku }\end{array}$} & \multicolumn{2}{|c|}{$\begin{array}{c}\text { Period - Sezon } \\
2014 / 2015\end{array}$} & \multicolumn{2}{|c|}{$\begin{array}{l}\text { Period - Sezon } \\
2015 / 2016\end{array}$} & \multirow{2}{*}{$\begin{array}{c}\text { Total } \\
\text { Razem }\end{array}$} \\
\hline & $\begin{array}{c}\text { extreme values } \\
\text { wartości ekstremalne }\end{array}$ & $\begin{array}{l}\text { total } \\
\text { razem }\end{array}$ & $\begin{array}{c}\text { extreme values } \\
\text { wartości ekstremalne }\end{array}$ & $\begin{array}{l}\text { total } \\
\text { razem }\end{array}$ & \\
\hline Autumn - Jesień & $14(371)-252(394)$ & 569 & $14(323)-178(396)$ & 843 & 1412 \\
\hline Winter - Zima & $16(382)-113(394)$ & 547 & $17(396)-130(394)$ & 495 & 1042 \\
\hline \multicolumn{2}{|c|}{ Period total - Razem w sezonie } & 1116 & & 1338 & \\
\hline \multicolumn{3}{|c|}{ Entire time span total - Razem w sezonach } & & & 2454 \\
\hline
\end{tabular}

Table 9. Mean carcass weights [kg] of the purchased roe deer doe carcasses (Capreolus capreolus L.) and their extreme values in relation to the hunting period and the season of the year

Tabela 9. Średnia masa [kg] skupionych tusz sarny kozy (Capreolus capreolus L.) oraz ich wartości ekstremalne (podane w nawiasach) w analizowanych sezonach łowieckich i porach roku

\begin{tabular}{lccc}
\hline $\begin{array}{c}\text { Hunting period } \\
\text { Sezon łowiecki }\end{array}$ & \multicolumn{2}{c}{ Season - Pora roku } & $\begin{array}{c}\text { Hunting period mean } \\
\text { Srednia } \\
\text { dla sezonu łowieckiego }\end{array}$ \\
\hline $2014 / 2015$ & wutumn - jesień & winter - zima & 17.7 \\
\hline $2015 / 2016$ & $(14.0-19.0)$ & $\begin{array}{c}18.2 \\
(16.0-20.0)\end{array}$ & 17.8 \\
\hline Season mean & $\begin{array}{c}17.9 \\
(14.0-20.0)\end{array}$ & $(16.0-19.2)$ & \\
Średnia dla pory roku & 17.6 & 18.0 & \\
\hline
\end{tabular}

In the period under analysis 27 roe deer fawn carcasses were delivered to the PSD from the examined zones (Table 10). 16 pieces were provided in the hunting period of 2015/2016, five more than in the previous hunting season. In both examined hunting periods very few of the hunting districts delivered roe deer kid carcasses to the PSD. The share of fawn carcasses bought as first quality game was $81.4 \%$. The total weight of the purchased carcasses in the analysed period amounted to $360 \mathrm{~kg}$ (Table 11). 
Table 10. Numbers (pieces) and quality (\% of class I carcasses) of the purchased roe deer fawn carcasses (Capreolus capreolus L.) from the selected hunting areas (numbers given in brackets) of the Siedlce district and their extreme values in relation to the hunting period and the season of the year Tabela 10. Liczba oraz jakość (udział tusz I klasy w \%) tusz sarny koźlęcia (Capreolus capreolus L.) skupionych z wybranych obwodów siedleckiego okręgu łowieckiego (podanych w nawiasach) oraz ich wartości ekstremalne, w zależności od sezonu łowieckiego i pory roku

\begin{tabular}{|c|c|c|c|c|}
\hline $\begin{array}{l}\text { Hunting period } \\
\text { Sezon łowiecki }\end{array}$ & $\begin{array}{c}\text { Season } \\
\text { Pora } \\
\text { roku }\end{array}$ & $\begin{array}{l}\text { Extreme values } \\
\text { Wartości ekstremalne }\end{array}$ & $\begin{array}{c}\text { Total } \\
\text { Razem }\end{array}$ & $\begin{array}{c}\text { Percentage of } \\
\text { class I carcasses } \\
\text { Procentowy } \\
\text { udział tusz } \\
\text { I klasy }\end{array}$ \\
\hline \multirow{2}{*}{$2014 / 2015$} & $\begin{array}{l}\text { autumn } \\
\text { jesień }\end{array}$ & $0(323,325,357,373,392,393,394,396)-2(356)$ & 4 & 100.0 \\
\hline & $\begin{array}{l}\text { winter } \\
\text { zima }\end{array}$ & $0(323,357,371,373,392,393,396)-3(394)$ & 7 & 85.6 \\
\hline \multicolumn{3}{|c|}{ Period total - Razem w sezonie } & 11 & 90.9 \\
\hline \multirow{2}{*}{$2015 / 2016$} & $\begin{array}{l}\text { autumn } \\
\text { jesień }\end{array}$ & $0(323,325,356,371,382,393)-4(392,394)$ & 12 & 75.0 \\
\hline & $\begin{array}{l}\text { winter } \\
\text { zima }\end{array}$ & $\begin{array}{c}0(325,356,357,371,373,382,393,394,396) \\
-2(323,392)\end{array}$ & 4 & 75.0 \\
\hline \multicolumn{3}{|c|}{ Period total - Razem w sezonie } & 16 & 75.0 \\
\hline \multicolumn{3}{|c|}{ Entire time span total - Razem w sezonach } & 27 & 81.4 \\
\hline
\end{tabular}

Table 11. Total carcass weights [kg] of the purchased roe deer fawn carcasses (Capreolus capreolus L.) from the selected hunting zones (numbers given in brackets) of the Siedlce district and their extreme values in relation to the hunting period and the season of the year

Tabela 11. Łączna masa [kg] tusz sarny koźlęcia (Capreolus capreolus L.) skupionych z wybranych obwodów siedleckiego okręgu łowieckiego (podanych w nawiasach) oraz ich wartości ekstremalne, w zależności od sezonu łowieckiego i pory roku

\begin{tabular}{|c|c|c|c|c|c|}
\hline \multirow{2}{*}{$\begin{array}{l}\text { Season } \\
\text { Pora roku }\end{array}$} & \multicolumn{2}{|c|}{$\begin{array}{c}\text { Period - Sezon } \\
2014 / 2015\end{array}$} & \multicolumn{2}{|l|}{$\begin{array}{l}\text { Period - Sezon } \\
2015 / 2016\end{array}$} & \multirow{2}{*}{$\begin{array}{c}\text { Total } \\
\text { Razem }\end{array}$} \\
\hline & $\begin{array}{c}\text { extreme values } \\
\text { wartości ekstremalne }\end{array}$ & $\begin{array}{l}\text { total } \\
\text { razem }\end{array}$ & $\begin{array}{c}\text { extreme values } \\
\text { wartości ekstremalne }\end{array}$ & $\begin{array}{l}\text { total } \\
\text { razem }\end{array}$ & \\
\hline $\begin{array}{l}\text { Autumn } \\
\text { Jesień }\end{array}$ & $11(371)-34(356)$ & 58 & $12(357)-54(392)$ & 155 & 213 \\
\hline $\begin{array}{l}\text { Winter } \\
\text { Zima }\end{array}$ & $12(356)-49(394)$ & 99 & $22(323)-26(392,396)$ & 48 & 147 \\
\hline $\begin{array}{l}\text { Period total } \\
\text { Razem w sezonie }\end{array}$ & & 157 & & 203 & \\
\hline $\begin{array}{l}\text { Entire time span total } \\
\text { Razem w sezonach }\end{array}$ & & & & & 360 \\
\hline
\end{tabular}

In the hunting period of 2015/2016 a higher weight of fawn carcasses was delivered to the depot, equalling $230 \mathrm{~kg}$, i.e. $46 \mathrm{~kg}$ more than in the previous one. More fawn carcasses were delivered in the autumn. The mean weight of the fawn carcasses supplied to the PSD from the examined zones ranged from $11 \mathrm{~kg}$ to $17 \mathrm{~kg}$ (Table 12). In the 2015/2016 hunting period the mean weight of the carcasses delivered to the PSD was $1.6 \mathrm{~kg}$ smaller in comparison with the previous period. The analyses of the mean weights of the purchased roe deer fawn carcasses did not reveal significant differences between the examined periods and seasons. 
Table 12. Mean carcass weights $[\mathrm{kg}]$ of the purchased roe deer fawn carcasses (Capreolus capreolus $\mathrm{L}$.) and their extreme values in relation to the hunting period and the season of the year

Tabela 12. Średnia masa [kg] skupionych tusz sarny koźlęcia (Capreolus capreolus L.) oraz ich wartości ekstremalne (podane w nawiasach) w analizowanych sezonach łowieckich i porach roku

\begin{tabular}{|c|c|c|c|}
\hline \multirow{2}{*}{$\begin{array}{l}\text { Hunting period } \\
\text { Sezon łowiecki }\end{array}$} & \multicolumn{2}{|c|}{ Season - Pora roku } & \multirow{2}{*}{$\begin{array}{l}\text { Hunting period mean } \\
\text { Srednia } \\
\text { dla sezonu łowieckiego }\end{array}$} \\
\hline & autumn - jesień & winter - zima & \\
\hline $2014 / 2015$ & $\begin{array}{c}14.5 \\
(11.0-17.0)\end{array}$ & $\begin{array}{c}14.1 \\
(12.0-16.3)\end{array}$ & 14.3 \\
\hline $2015 / 2016$ & $\begin{array}{c}12.9 \\
(12.0-15.0)\end{array}$ & $\begin{array}{c}12.0 \\
(11.0-13.0)\end{array}$ & 12.7 \\
\hline $\begin{array}{l}\text { Season mean } \\
\text { Średnia dla pory roku }\end{array}$ & 13.3 & 13.4 & \\
\hline
\end{tabular}

\section{CONCLUSION}

1. The depot purchased altogether 230 wild boar carcasses with the total weight of $13438 \mathrm{~kg}$ from all the analysed hunting zones in the examined periods. The hunting zones provided carcasses that highly differed in terms of the mean weight, varying from $28 \mathrm{~kg}$ to $123 \mathrm{~kg}$. The hunting period and season of the year factors were found to significantly affect the wild boar carcass weight means. In the hunting period of 2014/2015 the wild boar carcass mean weight was observed to be significantly higher in the summer in comparison with the same time of the following period. On the other hand, the wild boar carcass mean weight was significantly lower in the spring in the analysed time span. The number of carcasses delivered to the depot in the hunting period of 2015/2016 was more than 2.5-fold higher than previously, which indicates the presence of additional factors, such as numerous cases of game damage or the outbreak of the African Swine Fever in this area, contributing to the intensified shootings of the species.

2. 149 roe buck carcasses with a total weight of $2795 \mathrm{~kg}$ were purchased from the analysed zones. The mean carcass weight of roe bucks from a hunting zone ranged from $16 \mathrm{~kg}$ to $21 \mathrm{~kg}$. Altogether 133 roe deer female carcasses were purchased in the analysed hunting periods, with a total weight of $2454 \mathrm{~kg}$ and the mean weight varying from 14 to $20 \mathrm{~kg}$ depending on the hunting zone. 27 roe deer kid carcasses totalling $360 \mathrm{~kg}$ in weight were purchased in the examined hunting periods, with the mean weight of the roe deer kid carcasses from a given hunting zone varying from $11 \mathrm{~kg}$ to $17 \mathrm{~kg}$. No effects of the hunting period and season of the year on the mean carcass weight were identified for this particular species.

3. The carcasses of the examined species were mostly purchased as first quality game (ranging from $73 \%$ in the case of the wild boar to $91.3 \%$ for the roe deer females), which confirms these animals were shot in a proper manner.

\section{REFERENCES}

Bernués A., Olaizola A., Corcoran K. 2003. Extrinsic attributes of red meat as indicators of quality in Europe: an application for market segmentation. Food Quality Prefer. 14, 265-276. 
Dransfield E. 2003. Consumer acceptance - meat quality aspects, in: Consistency of quality 11th international meat symposium. Pretoria, RPA, 146-159.

Główna Inspekcja Weterynaryjna. 2016. Lista zakładów uprawnionych do wprowadzania produktów pochodzenia zwierzęcego na rynek krajowy, www.old.wetgiw.gov.pl, access: 16.11.2016.

Hoffman L.C., Wiklund E. 2006. Game and venison - meat for the modern consumer. Meat Sci. 74, 197-208.

Klasyfikacja dziczyzny, http://www.weles.pl/informacje, access: 16.11.2016. [in Polish]

Ngapo T.M., Dransfield E. 2006. British consumers preferred fatness levels in beef: surveys from 1955, 1982 and 2002. Food Quality Prefer. 17, 412-417.

Popczyk B. 2012. Problemy handlu dziczyzną, w: Problemy współczesnego łowiectwa. Red. D. Gwiazdowicz. Poznań, Ofic. Wydaw. G\&P, 137-150. [in Polish]

Rozporządzenie Ministra Rolnictwa i Rozwoju Wsi z 19 lutego 2016 r. o sanitarnym odstrzale dzików. DzU 2016, poz. 229. [in Polish]

Santos M.L.S., Booth D.A. 1996. Influences on meat avoidance among British students. Appetite 27, 197-205.

Skorupski M., Wierzbicka A. 2014. Dziczyzna jako źródło zdrowej żywności - problemy i perspektywy [Game meat as a source of healthy food - problems and prospects]. Stud. Mater. CEPL Rogów 38, 171-174. [in Polish]

Steenkamp J.E.M. 1997. Dynamics in consumer behaviour with respect to agricultural and food products, in: Agricultural marketing and consumer behaviour in a changing world. Eds. B. Wierenga, A. Van Tilburg, K. Grunert, J. E. M. Steenkamp, M. Wedel. Boston, USA, Kluwer Acad. Publ., 143-188.

Werpachowski M., Zalewski D. 2012. Dziczyzna - mięso niedoceniane przez polskich konsumentów [Wild meat - meat undervalued by Polish consumer]. Prz. Hod. 3-4, 29-31. [in Polish]

Ziembińska A., Krasnowska G. 2007. Zapewnienie bezpieczeństwa zdrowotnego w obrocie tuszami zwierząt łownych [The assurance of food safety in game carcas trading]. Żywn. Technol. Jakość 1(50), 16-25. [in Polish]

\begin{abstract}
Around $25 \%$ of acquired game animal carcasses are given to the hunters for their own personal use, the remainder is stored in game meat depots. The purpose of this paper is to characterize the purchased game meat, particularly: the game animal species, the amount and mass of purchased carcasses and the carcass class in selected hunting zones in the Siedlce Hunting District, including the impact of the hunting period and the season of the year. In total, the Game Meat Depot (PSD) purchased 230 boar carcasses from all the analysed hunting zones in the hunting periods included in this study, summing up to $12438 \mathrm{~kg}$ of total carcass weight. The mean carcass weight of boars purchased from the studied hunting zones was between 28 and $123 \mathrm{~kg}$. The study has shown a significant impact of the hunting period and season of the year on the mean boar carcass weight. 149 roebuck carcasses where purchased from the studied hunting zones, summing up to $2795 \mathrm{~kg}$ of total carcass weight, with the mean carcass weight between 16 and $21 \mathrm{~kg} .138$ roe deer doe carcasses where purchased during the autumn and winter of the studied hunting periods, summing up to $2454 \mathrm{~kg}$ of carcass weight, with the mean carcass weight between 14 and $20 \mathrm{~kg}$. 27 roe deer fawn carcasses where purchased, summing up to $360 \mathrm{~kg}$ of carcass weight, with the mean carcass weight between 11 and $17 \mathrm{~kg}$. The study did not reveal significant differences in the mean carcass weights between the hunting periods and seasons of the year for this species. Most carcasses of the researched species were ranked as first class game.
\end{abstract}

